\begin{tabular}{|l|l|l||}
\hline \multicolumn{2}{|c|}{ PublisherInfo } \\
\hline \hline PublisherName & $:$ & BioMed Central \\
\hline \hline PublisherLocation & $:$ & London \\
\hline \hline PublisherImprintName & $:$ & BioMed Central \\
\hline \hline
\end{tabular}

\title{
Shortening LINEs
}

\begin{tabular}{|l|l|l||}
\hline \multicolumn{2}{|c|}{ ArticleInfo } \\
\hline \hline ArticleID & $:$ & 4883 \\
\hline \hline ArticleDOI & $:$ & $10.1186 /$ gb-spotlight-20031117-01 \\
\hline \hline ArticleCitationID & $:$ & spotlight-20031117-01 \\
\hline \hline ArticleSequenceNumber & $:$ & 235 \\
\hline \hline ArticleCategory & $:$ & Research news \\
\hline \hline ArticleFirstPage & $:$ & 1 \\
\hline \hline ArticleLastPage & $:$ & 3 \\
\hline \hline & & RegistrationDate : 2003-11-17 \\
ArticleHistory & $:$ & OnlineDate $\quad$ 2003-11-17 \\
\hline \hline ArticleCopyright & $:$ & BioMed Central Ltd2003 \\
\hline \hline ArticleGrants & $:$ & \\
\hline \hline ArticleContext & $:$ & 130594411 \\
\hline \hline
\end{tabular}




\section{Cathy Holding}

Email: cholding@hgmp.mrc.ac.uk

LINE-1 (L1) elements are the mammalian version of autonomously replicating retrotransposable elements active via an RNA intermediate that lack long terminal repeats. They are very ancient, dating back about 100 million years, and distinctive families containing many thousands of members are found in plants, fungi, invertebrates, and vertebrates. Because of their ability to amplify themselves, they constitute about $30 \%$ of genomic DNA in mammals, and their mobility within the genome coupled with their disruptive effects have affected the evolution, structure, and function of mammalian genomes. L1 expression is elevated in certain cancers, reflecting a lack of control over both expression regulation and genetic damage.

In the November 16 Nature Genetics, Victoria Perepelitsa-Belancio and Prescott Deininger at the Tulane University Health Sciences Center report the discovery of the use of multiple canonical and noncanonical polyadenylation (polyA) sites in the A-rich region of L1 sequences in a cell- and tissuespecific fashion that limit the spread and consequent genetic damage of retrotransposons, revealing both a transposon survival mechanism and a previously unrecognized method of mRNA regulation by means of conventional 3' end formation in mammalian cells (Nature Genetics 2003, DOI:10.1038/ng1269).

Perepelitsa-Belancio and Deininger expressed an active human LINE1.3 construct followed by a mouse LINE construct in mouse NIH3T3 cell lines and observed bands on Northern analysis corresponding with full-length and truncated transcripts that could be attributed to the use of putative polyA sites in the sequence. Mutational inactivation of the strongest sites revealed that both noncanonical and classical neighboring polyA sites could be used, pointing to the redundancy of the regulatory system. Analysis of 3' RACE transcripts in chicken fibroblasts and Ntera2 cells confirmed their use. Removal of certain sites resulting in longer transcripts resulted in increased retrotransposon activity in HeLa cells, confirming the protective effects of truncation. Examination of the expressed sequence tag databases supported the process of 3 ' truncation of sequences in human and mouse.

"We showed that LINE-1 sequences support the use of a broad range of poly(A) sites that limit retroposition activity of the element, resulting in less retroposition and, therefore, less damage to their hosts' genomes... Our observation of a new application of the conventional mRNA 3' end formation extends the range of the known mechanisms for the control of mRNA levels in mammalian cells and provides additional understanding of the selective pressures that act on new retrotransposition events in reshaping the mammalian genome," conclude the authors. 


\section{References}

1. LINE drive: Retrotransposition and genome instability

2. Nature Genetics, [http://www.nature.com/ng/]

3. Tulane University Health Sciences Center, [http://www2.tulane.edu/hsc.cfm]

This PDF file was created after publication. 